\title{
Poverty Alleviation Through the Program Slums in the City of Kendari, Indonesia
}

\author{
Joko Tri Brata \\ University of Sulawesi Tenggara, Indonesia \\ E-mail: joko_tribrata@yahoo.co.id
}

La Ode Bariun

University of Sulawesi Tenggara, Indonesia

Asri Djauhar

University of Sulawesi Tenggara, Indonesia

Andi Gusti Tantu (Corresponding author)

University of Sulawesi Tenggara, Indonesia

E-mail: joko_tribrata@yahoo.co.id

Received: Dec. 8, 2018 Accepted: December 17, 2018 Published: December 24, 2018

doi:10.5296/jee.v9i2.14388ＵRL: https://doi.org/10.5296/jee.v9i2.14388

\begin{abstract}
The long-term goal of the concept of poverty reduction is to give the same level of welfare for the Indonesian people, and in this research is the development of innovative Models of Poverty Reduction, with the subject on (1) How the application design model of the institutional prevention of poverty through interface Program Quality Improvement of Slums and (2) how the efforts in governance of slum through simulation integration with poverty alleviation. The method used is the description by sharpening the Focus Group Discussion (FGD) about the handling of the slums in the city of Kendari and intervention efforts Increase the quality of housing and slums, so that the governance model can be used in other areas in Southeast Sulawesi.
\end{abstract}

Keyword: Mixed Program, Poverty alleviation, City of Kendari 


\section{Introduction}

View Goldsmith in (De Smet \& Marchal, (2010; Tribrata , 2014) explains that the advantages of the network model are the presence of "specialization, innovation, speed, and flexibility, as well as increased range". Is the weight of the Innovation is to collaborate the unit in the unit organization so as to create a new unit that is more modern and flexible. In the context of the network, mentioning that the activities of the parties in the network organization related to program implementation are beneficial, in an effort to achieve a common goal.

Meanwhile (Mustonen-Ollila \& Lyytinen, 2003; Tribrata , 2014) re-confirms that the pattern of innovation in the concept network between organizations that have an interest and the same goal, no longer appropriately approached through an economic approach alone, but it needs to be approached with a new approach, namely the network approach to welfare, the basic core model this approach requires the unification of resources of each organization collaborated on an order towards the welfare of the in that context, a poverty reduction program in the analogy can be approached with the approach of tackling the untidiness (Tribrata, 2017), where the basic concept is the program "Nawacita" the third is to build Indonesia from the periphery by strengthening the areas and villages in the framework of the unitary state. With this Program it is confirmed in the program 100-0-100 that indicate how access to drinking water are met for the community achieved 100 percent, 0 to two is how the slum was lost to the target of 0 percent, and 100 the third is how environmental sanitation are met well.

The Program is done considering the majority of the population in developing countries such as Indonesia will live in urban areas, because in the period of the last forty years, Indonesia has experienced urban population growth, high population growth rate in urban areas reaches an average of $2.75 \%$ per year and is estimated at the end of the year 2025 there are approximately $60 \%$ of Indonesia's population will live in urban areas (Ministry of PUPR, 2016). The high growth is not only due to natural population growth but also urbanization. Population growth has implications on the increasing density of settlements, the need for a decent home and affordable, as well as the needs of the basic services and system management of the settlements, are adequate. (Ariyanto, 2015).

Increasing population growth in urban areas which are not followed by the region's readiness to respond to such phenomena will also pose complex issues for the region is unemployment, slums, congestion, declining environmental quality, and social inequality. The phenomenon of urban population growth is high and not controlled also influential in the destruction of the urban system with the advent of urban sprawl or the construction of new cities that are not directional.

Distribution of the population of the City of Kendari uneven cause of social inequality in a particular region resulting in the emergence of settlements-slums in various regions, as a result of social problems i.e. poverty, in addition, there are also health problems because of the difficulty of getting clean water worth and the absence of adequate sanitation. Environmental pollution also occurs because of the household waste is thrown away. Problems about the environment of housing and settlement occur because of the imbalance of 


\section{Macrothink}

the availability of land with the population. the distribution of slums in the City of Kendari are generally characterized by settlements of dense population with the quality of the environment and inadequate infrastructure.

\subsection{The General Overview of the Region}

The Slums of the City of Kendari has a wide 497,27 Ha in 55 villages, where the slum areas continue to experience a decrease in quality or deteriorate (deteriorated) both in physical, economic and social culture. Housing and settlements that grow and develop with the quality of housing below a minimum standard (roads, sanitation and drinking water).

\section{Research Methods}

The method of research is trying to decipher the model that has been obtained in our prior study and testing of this model is to formulate the institutional model that is valid for the improvement of the welfare of the community.

The form of the deepening of the material carried out the deepening of the through Focus Group Discussion (FGD)

\section{Results and Discussion}

\subsection{Picture of the Slums of the City of Kendari}

The first findings of our research in 2013, confirmed that TKPKD is a "Setting Institutional", be clarified again with a picture that the nationwide poverty Reduction in a coordinated manner to do with the formation of TKPKN.

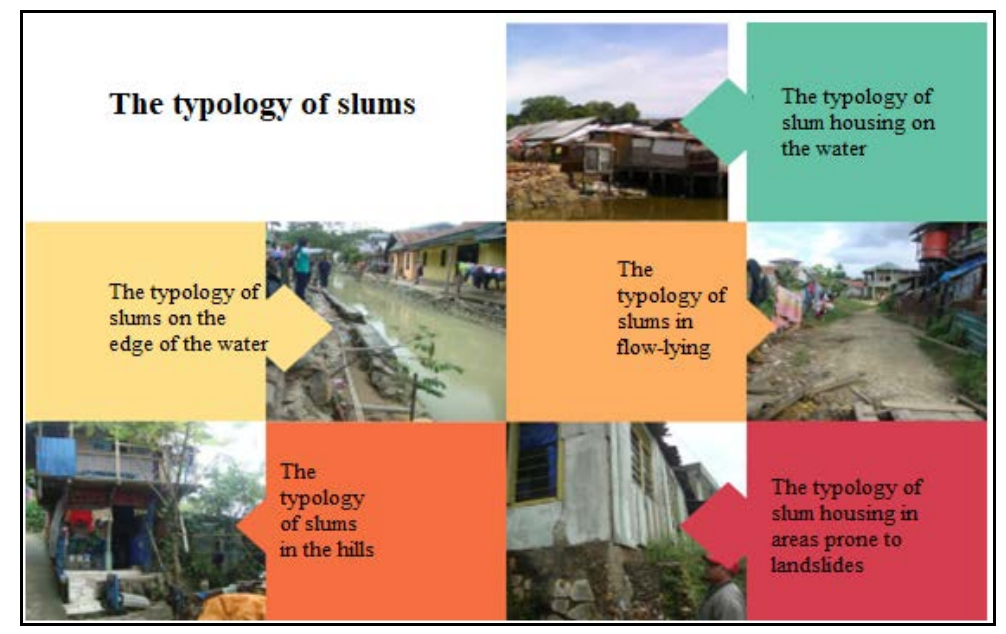

Figure 1. The typology of slums

While it is concerned with the development of the settlements in the city of Kendari, not in spite of the rapid rate of growth of population, either because of the factors of the growth and because of the urbanization factor. Along with population growth, the provision needs to be infrastructure and settlements increased in terms of both quality and quantity, so that the effect on the bearing capacity of infrastructure and environment of settlements which in turn contributes to the occurrence of slums. The handling of the slums in the city of Kendari is 


\section{I Macrothink}

done by applying the concept approach to the characteristics and typology of the region, the research results give a picture that the Typology of Slums of the city of Kendari is divided into three clusters namely cluster in the center of the city, The coastal cluster along the river.

\subsection{Slum City Centre}

The housing and slum emerging in the downtown area a result of the quality of the economy that is getting low and the density of settlements as well as the rapid rate of population growth due to factors of urbanization. This factor occurs due to the use of empty land in the center of the city in the wake of the absence of regulation and planning. As the impact of poverty in rural areas, making urbanization that impact negatively on the development of the City, namely the increasing demand for the provision of facilities and infrastructure of the settlements which eventually lead to the slums, it is because of the imbalance between the rate of increase in population with the rate of construction of residential facilities. The imbalance between the needs with the provision of infrastructure facilities and housing with a request will impact on the quality of infrastructures such as the area of the house where lived below $6 \mathrm{~m} 2$ /person and directly not or have less access to other public services such as clean water, sanitation, and others.

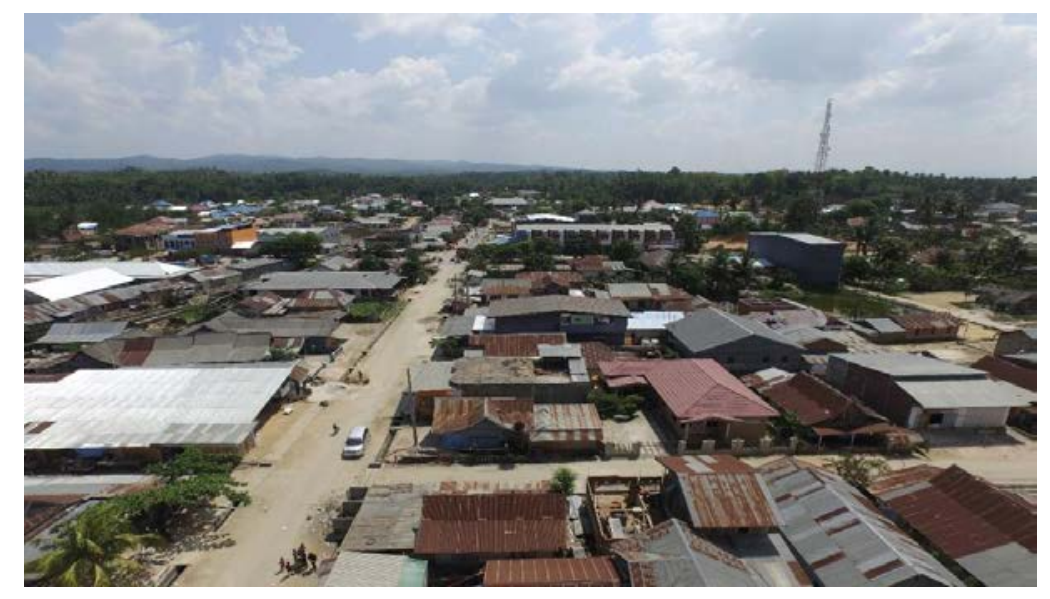

Figure 2. Slum City Centre

\subsection{The Slums of the Coastal Region}

The existence of the coastal region have the meanings located in the territory of the city of Kendari because it is a transitional area between marine and terrestrial ecosystems, as well as having the potential of natural resources and environmental services that is reflected from the magnitude of the biodiversity, the potential for aquaculture the beach and the sea as well as marine tourism. The main priorities of development in coastal areas, among others, to the center of the development of tourism, transportation, and ports, but the condition of other communities make the coastal region as a settlement area. Some region which is where the growth of slum areas either directly adjacent to the Banda Sea and the Gulf of Kendari as the Kambu sub-district, Abeli sub-district, Poasia sub-district, Kendari sub-district, Mandonga sub-district, West Kendari sub-district, and Kadia sub-district. This happens because of the lack of coordination in the issuance of a certificate of property rights. Based on the result of 


\section{Macrothink}

the verification shows that there is some area that is supposed to be the sea and the mangrove forest has been certified.

The growth of slums in the coastal area don't regardless of the lack of supervision coupled with the lack of the knowledge society patterns of land use based spatial plan of the city of Kendari so that people doing construction by erecting shacks wild in the area which resulted in the settlement environment that is dense and irregular.

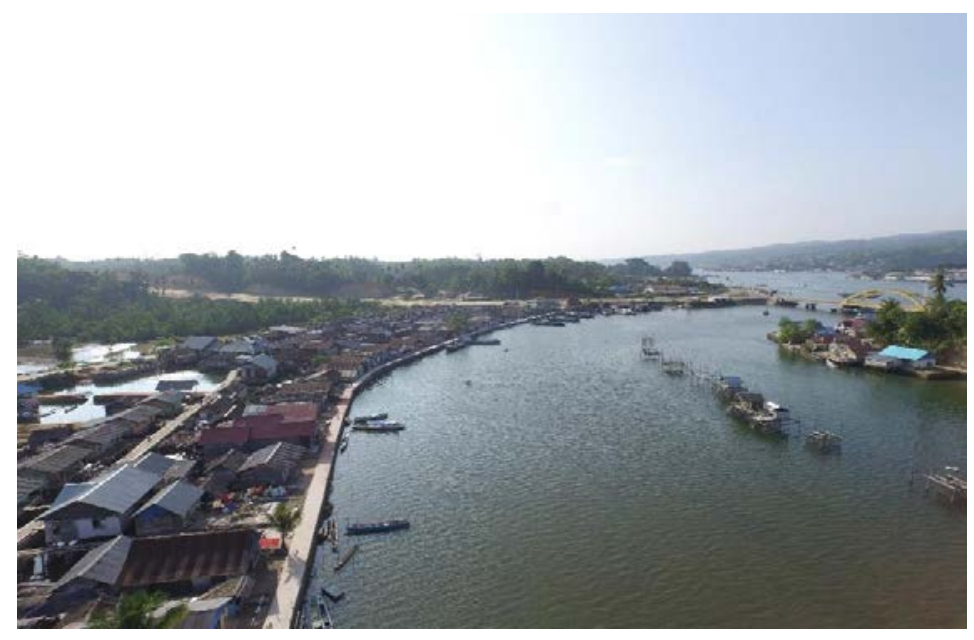

Figure 3. The Slums of The Coastal Area

The slums is a problem faced by the Government of Kendari city, especially the area of housing and settlements located on the banks of the river, which generally develops in a linear manner or follow the flow of the river with the construction of buildings house low-quality and not supported with the basic infrastructure of settlements such as, roads, sanitation and access to drinking water.

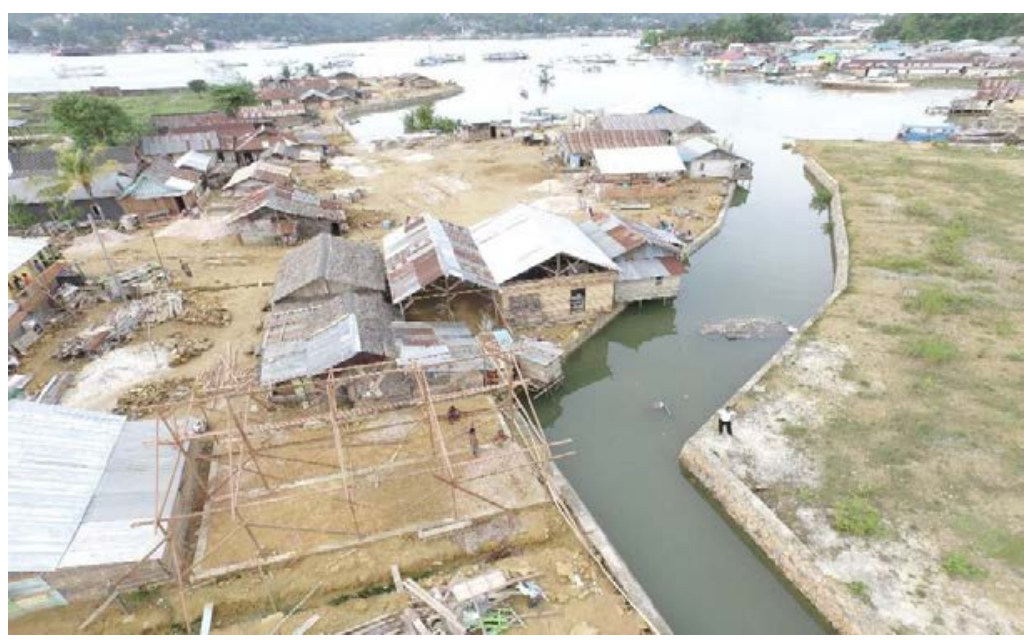

Figure 3. The Slums Along The River 


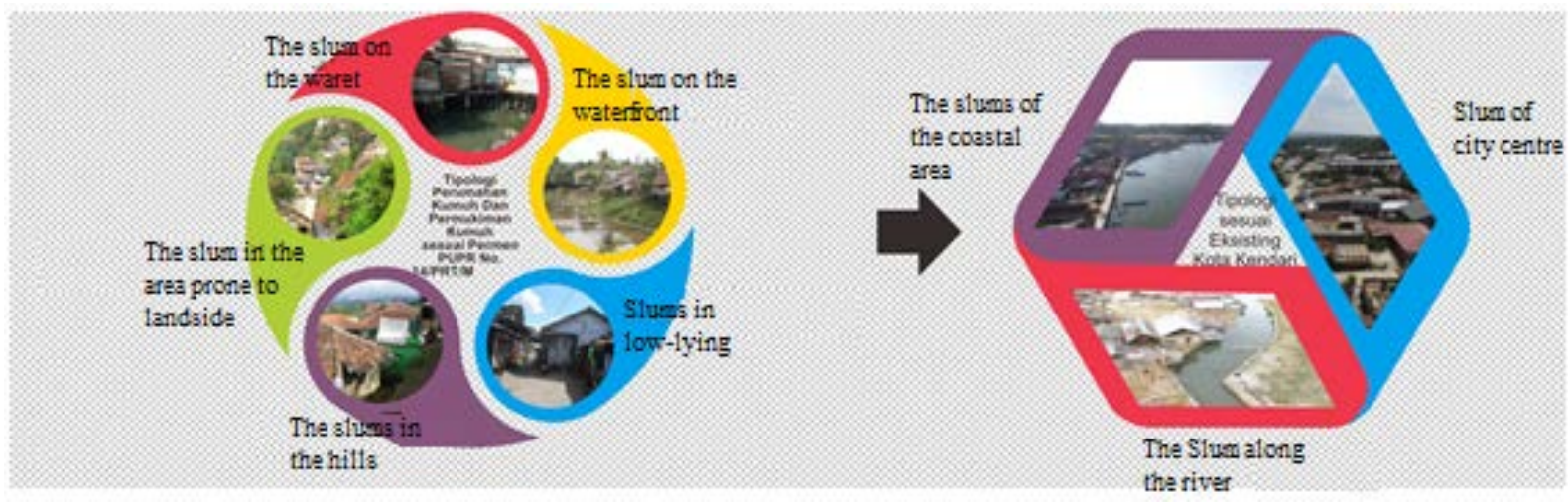

Figure 4. The analogy of the transformation of the typology of slum housing in the city of Kendari

\section{Conclusion}

From the results of research, obtained a conclusion that the transformation of the typology of slums theoretically, provide an overview of other related clusters of slums in the city of Kendari.

\section{The Effort of Handling}

In efforts to alleviate poverty through the handling of the slums reached the concept of prevention and quality improvement efforts;

1. In an effort to prevent the onset of housing and slums, supervision and control, too: the Suitability of a building permit, the determination of technical standards and the inspection effort according to the applicable regulations and no less important is the optimization of the role of society in empowering the community.

2. In relation to model quality Improvement is the effort of handling the slums by the way

a. Restoration is the Repair, rebuilding, a buddy of settlements.

b. Rejuvenation is the effort to realize the settlement area in order to protect the safety and security of the community

c. Resettlement is the Transfer of the community from a location that may not be rebuilt/ not in accordance with the spatial plan or areas prone to disaster/danger to goods or human beings.

\section{References}

De Smet, R., \& Marchal, K. (2010). Advantages and limitations of current network inference methods. Nature Reviews Microbiology. https://doi.org/10.1038/nrmicro2419

Mustonen-Ollila, E., \& Lyytinen, K. (2003). Why organizations adopt information system process innovations: A longitudinal study using diffusion of innovation theory. Information Systems Journal. https://doi.org/10.1046/j.1365-2575.2003.00141.x 
Barnard, C. I. (1938). Function The Executif. Cambridge. Mass. Harvarad Univ Press.

Djatnika, D. U. (2009). Peranan Pendidikan Dalam Pengentasan Kemiskinan, Jurnal Ilmu Administrasi Dan Kebijakan Publik (JIAKP), 6(1), 1-12.

Easton, D. (1953). The Political System, New York: Knopf, Frederickson, George H. 2003. The State of Social Equity in American Public Administration. American Society for Public Administration, 28(3). Retrieved from http://www.aspanet.org/scriptcontent/ word/ Accomplishments 2005. doc

Frederickson, H. G., \& Kevin, B. S. (2003). The Public Administration Theory Primer. USA: Westview Press.

Goldsmith, S., \& Donald, F. K. (editor). (2009). Unlocking The Power Of Network: Keys To the Hight Performance Government, ash institute for Democratic governance and innovation John F. Kennedy School of Government Harvard University, Brookings institution press Washington, D.C.

Kamuli, S. (2012). Birokrasi Negara sedang Berkembang. Jurnal Inovasi, 9(2), 2012.

Kasmad, R. (2015). Jaringan Pengembangan Kapasitas Organisasi Publik, Studi Kasus Penguatan Organisasi Terintegrasi dalam Implmentasi Kebijakan PKL di Kota Makassar, Makalah disajikan pada Seminar Nasional IAPA Sulselbar, 6-7 April 2015.

Moleong, L. J. (1997). Metodologi Penelitian Kualitatif. Edisi Revisi. Cetakan Kedua Puluh Empat. Remaja Rosdakarya. Bandung.

Marbun, B. N., \& Kota, S. H. (1994). Indonesia Masa Depan: Masalah dan Prospek. Jakarta: Erlangga.

Robbins, S. P. (1995). Teori Organisasi: Struktur, Desain dan Aplikasi. Jakarta: Arcan.

Sugiyono. (2011). Metode Peneltian Kuantitatif, Kualitatif, dan R dan D, Penerbit Alfabeta, Bandung.

Stoner James, dkk. (1996). Manajemen, Edisi Bahasa Indonesia, Jakarta . PT. Renhallindo.

Tribrata, J. (2013). Analisis Model Jaringan Organisasi, Penelitian Fundamental Dana Hibah Diktir Tahun 2013.

Tribrata, J. (2014). The Organisation Network In Reduccing Poverty at Kendari City, IOSR ; Journal Of Humanitities and Social Sciense, 19(1), 09-14.

Tribrata, J. (2015). Redesigning Poverty Alleviation Organization in Kendari. Jurnal Internasional Journal of Public Administration and Governance, 5(3), 10-20. http:// dx.doi.org/10.5296/jpag. v5i3.8078

Tribrata, J. (2017). Model Poverty Based Collaboration Disampaikan Pada International Conferences, "Scientific Publication Toward Global Competitive Higher Education. 21 -22 Januari 2017, UNM Makassar. 


\section{Macrothink}

Journal of Environment and Ecology

ISSN 2157-6092

2018, Vol. 9, No. 2

Tribrata, J. (2018). Program Effectiveness Poverty Reduction in the Context of Integrity, Prosiding Seminar yang Disampaikan Pada International Conference on Enviromental Awareness, 9-11 Maret2018, ICEASD Kendari

Undang-Undang Nomor 1 Tahun (2011). tentang Perumahan dan Kawasan Permukiman.

\section{Copyrights}

Copyright for this article is retained by the author(s), with first publication rights granted to the journal.

This is an open-access article distributed under the terms and conditions of the Creative Commons Attribution license (http://creativecommons.org/licenses/by/4.0/) 